\title{
Teaching Mathematical Functions Using Geometric Functions Approach and Its Effect on Ninth Grade Students' Motivation ${ }^{1}$
}

\author{
Veysel Akçakın \\ Asst. Prof., Usak University, Usak, Turkey, veysel.akcakin@usak.edu.tr
}

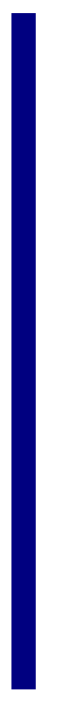

\begin{abstract}
The purpose of this study is to investigate the effects of using geometric functions approach on 9th grade students' motivation levels toward mathematics in functions unit. Participants of this study were 87 students who were ongoing in the first year of high school in Turkey. In this research, pretest and posttest control group quasiexperimental design was used. In the experimental group I, geometric functions approach and dynamic mathematics software which supported the mathematics teaching were used. In the experimental group II, dynamic mathematics software which supported the mathematics teaching was used. In the control group, traditional mathematics teaching method was used as a teaching method. The data of this study were collected by Students' Motivation toward Mathematics Learning questionnaire (SMTML). Before the experimental process, there was no statistically significant difference between students' motivation levels toward mathematics. After the experimental process, there was not a significant difference between experimental group I, experimental group II and control groups except for achievement goal dimension post-test scores. In achievement goal dimension there was a statistically significant difference between groups. The results of this study indicate that using geometric functions approach in the learning process of function concept has a significant effect on students' achievement goal motivation.
\end{abstract}

Keywords: geometric functions, motivation, functions, GeoGebra, ninth-grade students

\section{INTRODUCTION}

Concrete models are necessary for teaching abstract subjects such as mathematics. Function, one of the important basics of mathematics, is a difficult subject to understand. In order to learn the mathematics easier, it is necessary to analyse the efficiency of innovative approaches such as geometric functions approach. "Geometric functions refer to geometric transformations of a point in the plane - functions that have geometric points as their input and output" (Steketee, 2012, p.1). According to

\footnotetext{
${ }^{1}$ This research was produced from the author's doctoral dissertation.

Citation: Akçakın, V (2018). Teaching Mathematical Functions Using Geometric Functions Approach and Its Effect on Ninth Grade Students' Motivation. International Journal of Instruction, 11(1), 17-32. https://doi.org/10.12973/iji.2018.1112a
} 
Common Core State Standards for Mathematics, students should "describe transformations as functions that take points in the plane as inputs and give other points as outputs" (Common Core State Standards Initiative, 2010, p. 76). Steketee (2012) states that geometric functions approach should be given importance when teaching functions in terms of cognitive, kinaesthetic, visual, and structural reasons. As to Steketee, cognitive reason is related to independent variable, dependent variable and the rule used for obtaining dependant variable from the independent variable, which are three basic components of function concept. In terms of kinaesthetic reason, students can create independent variable, and they can change independent variable with simple drag motion. Visual reason is related to the observation of function behaviour by students. The change is visual and dynamic with geometric functions approach. Structural reason is related to students' comprehension of some concepts such as domain, range, symbolic display of function and set matching in composite functions. It is difficult for students to understand domain and range terms in the beginning of learning functions since they are confusing and there is no concrete object to define them (Steketee, 2012). Undoubtedly, it is crucial to use advanced technologies such as dynamic mathematics software for the application of this approach.

The use of technology in mathematics education can affect the cognitive and affective characteristics of students, which are generally neglected in teaching process (Bakar, Ayub, Luan, \& Tarmizi, 2010). Thus, it is necessary to analyse both cognitive and affective features of the individuals in education activities, which support their affective and cognitive skills. Motivation, which is an affective feature, is one of the preconditions of learning (Bacanlı \& Şahinkaya, 2011) since people with high motivation are more successful than the ones with low motivation even though both groups of people have the same capacity and opportunity (Wlodkowski, 2008).

Students would like to become successful learners for various reasons, which are generally classified as inner and external. Some of them want to be successful in order to be appreciated by others, to be a productive person or to show others how intelligent they are (Urdan \& Maehr, 1995). According to Urdan and Maehr (1995), goals are students' perceptions and beliefs about academic achievement. In a research, students said that their learning was related to external reasons such as competition, getting award from teacher and inner reasons such as satisfying their curiosity (Tuan, Chin \& Shieh, 2005). While motivation toward performance goal carries the features of external motivation, motivation toward achievement goal has the features of inner motivation (Pintrich \& Schunk, 2002). These perspectives may affect the student motivation in different ways (Urdan \& Maehr, 1995). Similarly, according to Brophy (2010), learning outputs of the students who approach the same target with different target guidance will be different, too. The students motivated for learning goal tend to become skilful. However, the ones motivated for performance goal tend to escape from regarding themselves as qualified or not to be seen as disqualified (Slavin, 2006).

Studies on motivation have usually focused on general motivation beliefs of the students such as target, explanation and value. Yet, the subject taught and learned hasn't been studied in detail. Many researchers state that motivation of students should be analysed 
in terms of the course (Lee \& Brophy, 1996; Tuan, Chin \& Shieh, 2000). However, there are few studies on motivation in mathematics education. Therefore, it is important to examine students' motivation toward mathematics learning. Although there are theoretical studies indicating that the geometric functions approach is effective in mathematics education (Steketee, 2012; Steketee, \& Scher, 2016), such empirical studies haven't been encountered. As a step in enhancing our understanding of the geometric functions approach on motivation for students to learn mathematics, the purpose of this study is to investigate the effects of using geometric functions approach on 9th grade students' motivation levels toward mathematics in functions unit.

Within this context, the following research problem is tried to be answered in this study: Does using geometric functions approach affect 9th grade students' levels of motivation toward mathematics in function unit? To this end, the following sub problems were proposed for the study:

1. Is there a significant difference between Experimental I, Experimental II and Control groups considering the post-test mean scores obtained from SMTML questionnaire dimensions?

2. Is there a significant difference within Experimental I, Experimental II and Control groups considering the mean scores obtained from SMTML questionnaire dimensions (pre-test and post-test)?

\section{METHOD}

\section{Research Design}

Instead of random assignment of the students to the groups, the study was performed using intact groups. No matter how important random assignment is for experimental design, it is not always possible to use this method. Classes are generally not changed in education studies, and they are performed with intact groups. Therefore, the student adaptation to the environment does not become a problem. Otherwise, if they are assigned to groups randomly, there may be some adaptation problems. In this research, pre-test and post-test control group quasi-experimental design was used. The groups were chosen randomly in the experimental group I, experimental group II and the control group. Then, the groups were compared in terms of being equal or not using SMTML questionnaire dimensions. According to the dimensions, groups were found to be equal before the experimental process. Table 1 shows the symbolic representation of the research design.

Table 1

Symbolic representation of research design

\begin{tabular}{|c|c|c|c|}
\hline Groups & Pretest & Process & Posttest \\
\hline $\begin{array}{l}\text { Experimental } \\
\text { Group I }\end{array}$ & M & $\begin{array}{l}\text { Geometric functions approach and dynamic mathematics } \\
\text { software which supported the mathematics teaching }\end{array}$ & M \\
\hline $\begin{array}{l}\text { Experimental } \\
\text { Group I }\end{array}$ & M & $\begin{array}{l}\text { Dynamic mathematics software which supported the } \\
\text { mathematics teaching }\end{array}$ & M \\
\hline $\begin{array}{l}\text { Control } \\
\text { Group }\end{array}$ & M & Traditional mathematics teaching & M \\
\hline
\end{tabular}

M: Students' Motivation toward Mathematics Learning Questionnaire 


\section{Participants}

This study was conducted with three intact ninth-grade classes in an Anatolian High School in a town of Ankara in the second term of 2013-2014 academic year. Two of the classes were chosen as the experimental groups while the other group was chosen as a control group randomly. A total of 87 students, 29 in each group, participated in the study voluntarily. There were 13 female and 16 male students in the experimental group I; 12 female and 17 male students in the experimental group II; 14 female and 15 male students in the control group.

\section{Experimental Process}

Experimental process lasted 4 weeks, as 6 hours per week, 24 hours in total. In the experimental group I, geometric functions approach and dynamic mathematics software which supported the mathematics teaching were used. In the experimental group II, dynamic mathematics software which supported the mathematics teaching was used. In the control group, traditional mathematics teaching method was used as a teaching method. The same activities were performed in all groups, but the activities were organized in accordance with the mentioned approaches. SMTML questionnaire was implemented before and after the experimental process. In the study, independent variables were the teaching methods applied on each groups. The dependent variable was the scores obtained from SMTML. Due to the fact that the teachers of the groups were different, the experimental implementations were carried out by the researcher. Thus, the effect of the teacher factor on dependent variable could be avoided. All groups had interactive white boards (IWB) and they were used during the courses. In the control group, white board, if necessary, IWB were used. In the experimental groups, dynamic mathematics software was used on IWB and if necessary, white board was used. Dynamic mathematics software was used as a tool of presentation in this process. GeoGebra, dynamic mathematics software, was utilized during the activities in the experimental group I and II. Activities about geometric functions were firstly applied in the experimental group I. Display of sample geometric functions approach activity is given in Figure 1.

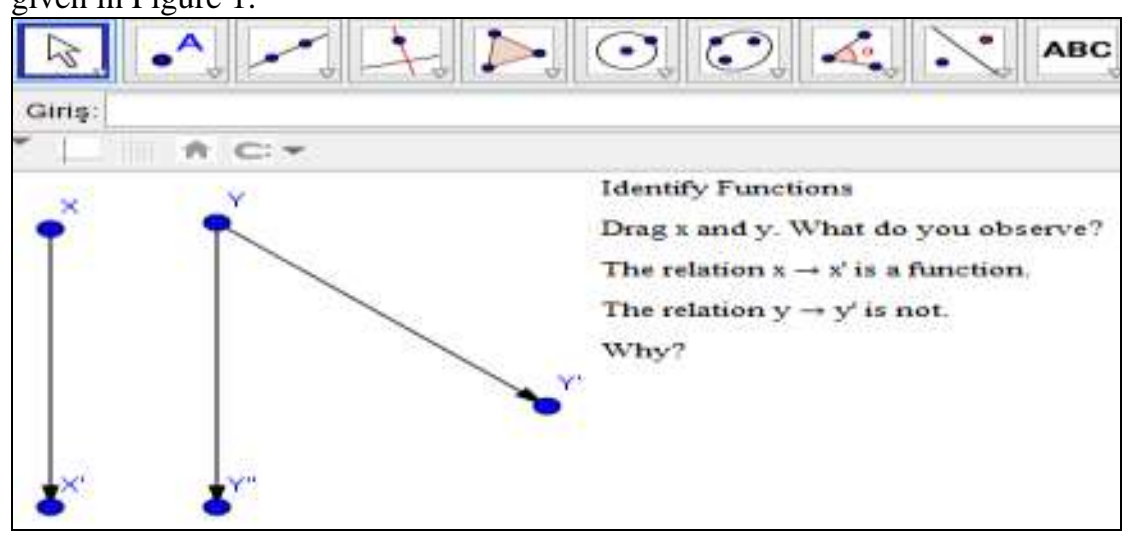

Figure 1

An example of an activity about Geometric Functions Approach 
Some short of information about GeoGebra software was given to the students in the experimental group I and II before the experimental process. The dynamic mathematics software was used on the IWB as a visual presentation tool by the researcher since there was no computer lab in the school. For example, vertical line test was shown by GeoGebra in the experimental group I and II and it was shown using traditional method in the control group. Figure 2 shows GeoGebra application used in the experimental group I and II. In this activity, different graphics were demonstrated to the students. After function and no function examples, vertical line test was applied with the help of slider. For example, the graphic in Figure 2 was introduced as a not function graphic and vertical line test was performed by slider. In other examples, function graphic samples were given and the same test was applied. So, it was aimed that the students could understand the logic of the vertical line test. Similar examples were drawn on white board in the control group and the same way was followed. During the process, it was observed that some of the students in the control group had different conceptual meanings. These kinds of situations were identified and corrected by the researcher.

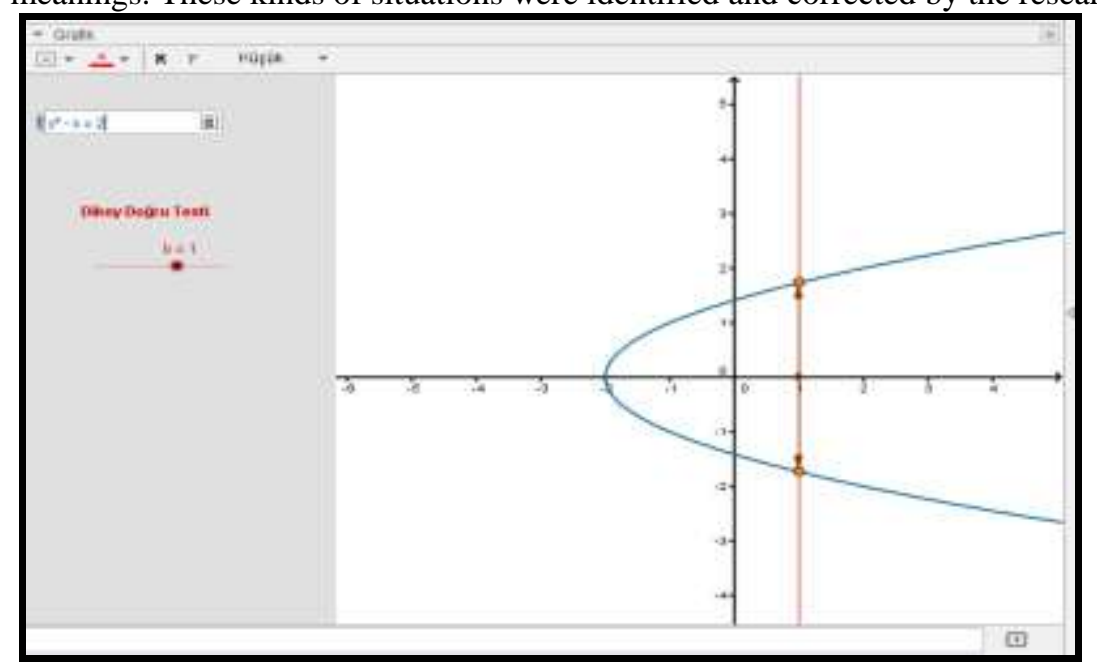

Figure 2

An example of an activity applied to Experiment I and Experiment II groups

For instance, the students assumed that vertical line test meant drawing vertical lines on different points of the graphic (e.g. 4 or 5 times) and finding how many points they were intersecting. However, such a misunderstanding did not exist in the experimental groups. It might be because of the fact that the continuous motion of slider in dynamic mathematics environment could not be realized in the control group.

\section{Data Collection Tool}

In this study, the high school students' motivation levels toward mathematics learning were measured by using SMTML questionnaire. The original questionnaire includes 35 
items and 6 dimensions (self-efficacy, active learning strategies, value of science learning, performance goal, achievement goal, learning environment stimulation) and it was developed for the students from 12-15 age group by Tuan et al. (2005). SMTML questionnaire consisted of 35 Likert-type questions. The questionnaire was adapted to Turkish language using the forward translation method. In forwards translation technique, it is easier to take notice of cultural, linguistic, and psychological differences (Hambleton, 2005). In this technique, the questionnaire in the source language is translated into the target language by one or more than one translators. Later, the crosscheck of the questionnaires in both languages is controlled by other translators. Sometimes, an expert, not a translator, checks the questionnaire in target language as a final stage and makes necessary changes (Hambleton, 2005). Therefore, SMTML questionnaires were firstly translated from the source language English to the target language Turkish by two researchers independently. Then, an expert in both languages and mathematics examined the crosscheck between the questionnaires in source and target languages and made some suggestions. Required modifications were made on the questionnaires by considering the suggestions. Finally, the Turkish form of the questionnaire was controlled by an expert in Turkish language in order to understand whether the items were clear enough in terms of linguistics. Thus, SMTML questionnaire was prepared for the pilot study. The final form of the questionnaire was tested in terms of construct validity.

Adaptation of the questionnaire translated into Turkish was made with 462 students. The six dimensional structure of the questionnaire was confirmed by explanatory factor analysis. After the varimax rotation method, the percentages of the dimensions explaining the motivation structure were found to range between 7.017 and 10.776. Totally, all the dimensions were found to explain $54.903 \%$ of the motivation structure. Active learning strategies dimension explained $10.776 \%$ of the variance. It was $10.294 \%$ for self-efficacy dimension, $10.258 \%$ for achievement goal dimension, $9.051 \%$ for mathematics learning dimension, $7.508 \%$ for learning environment stimulation dimension and $7.017 \%$ for performance goal dimension. The construct validity of SMTML questionnaire was determined by explanatory factor analysis. Cronbach alpha reliability of the dimensions ranged between 71 and 86. SMTML questionnaire includes 33 items and 6 dimensions. The scores obtained from the dimensions constituting the questionnaire could not be added. Each dimension score could be evaluated one by one. According to the findings obtained from the studies of SMTML questionnaire's cultural adaptation, reliability and validity, the questionnaire was found to be convenient for Turkish language and it could be used to measure the motivation toward mathematics in high schools with reliability and validity.

\section{Data Analysis}

Before and after the experimental implementation, the normality of the data about SMTML questionnaire dimensions were checked using Shapiro-Wilk normality test and the homogeneity of variances were checked by Levene's test. When normality analysis and homogeneity of variances analysis of SMTML questionnaire dimensions were evaluated, non-parametric tests were found to be more suitable for the comparisons 
between groups. Differences between several independent groups (more than two) were tested using Kruskal-Wallis $H$ test. Differences between two independent groups were tested by Mann-Whitney $U$ test and Wilcoxon signed-rank test was used to compare the two related conditions.

\section{FINDINGS}

It is important whether the groups are equal before the experimental procedure. Therefore, the equality of the groups was checked before the experimental procedure. The Kruskal Wallis $H$ test results showing the comparison of the groups in terms of pretest scores obtained from SMTML questionnaire dimensions are given in Table 2.

Table 2

Kruskal Wallis $\mathrm{H}$ test results regarding the comparison of the groups' pre-test scores obtained from SMTML questionnaire dimensions

\begin{tabular}{|c|c|c|c|c|c|c|}
\hline Dimensions & Groups & $\mathrm{N}$ & $\begin{array}{l}\text { Mean } \\
\text { ranks }\end{array}$ & $\mathrm{H}$ & $\mathrm{p}$ & $\eta^{2}$ \\
\hline \multirow[t]{3}{*}{ Self-efficacy } & Experimental I & 29 & 46.91 & \multirow{3}{*}{0.711} & \multirow{3}{*}{.701} & \multirow{3}{*}{0.008} \\
\hline & Experimental II & 29 & 43.72 & & & \\
\hline & Control & 29 & 41.36 & & & \\
\hline \multirow{3}{*}{$\begin{array}{l}\text { Active learning } \\
\text { strategies }\end{array}$} & Experimental I & 29 & 44.24 & \multirow[t]{3}{*}{2.564} & \multirow[t]{3}{*}{.277} & \multirow{3}{*}{0.03} \\
\hline & Experimental II & 29 & 38.59 & & & \\
\hline & Control & 29 & 49.17 & & & \\
\hline \multirow{3}{*}{$\begin{array}{l}\text { Value of mathematics } \\
\text { learning }\end{array}$} & Experimental I & 29 & 42.91 & \multirow[t]{3}{*}{1.751} & \multirow[t]{3}{*}{.417} & \multirow[t]{3}{*}{0.02} \\
\hline & Experimental II & 29 & 40.28 & & & \\
\hline & Control & 29 & 48.81 & & & \\
\hline \multirow[t]{3}{*}{ Performance goal } & Experimental I & 29 & 35.83 & \multirow[t]{3}{*}{5.907} & \multirow[t]{3}{*}{.052} & \multirow[t]{3}{*}{0.07} \\
\hline & Experimental II & 29 & 51.88 & & & \\
\hline & Control & 29 & 44.29 & & & \\
\hline \multirow[t]{3}{*}{ Achievement goal } & Experimental I & 29 & 43.38 & \multirow[t]{3}{*}{0.851} & \multirow[t]{3}{*}{.653} & \multirow[t]{3}{*}{0.01} \\
\hline & Experimental II & 29 & 41.36 & & & \\
\hline & Control & 29 & 47.26 & & & \\
\hline \multirow[t]{3}{*}{$\begin{array}{l}\text { Learning environment } \\
\text { stimulation }\end{array}$} & Experimental I & 29 & 42.84 & \multirow[t]{3}{*}{1.094} & \multirow[t]{3}{*}{.579} & \multirow[t]{3}{*}{0.013} \\
\hline & Experimental II & 29 & 41.28 & & & \\
\hline & Control & 29 & 47.88 & & & \\
\hline
\end{tabular}

$$
* p<.05
$$

According to the findings in Table 2, it can be seen that no statistically significant difference was found between pre-test scores of the experimental group I, experimental group II and control groups obtained from SMTML questionnaire dimensions, which means that they were equal before the experimental process. Besides, it is also seen that the effect sizes were not large. 
The first sub problem: Is there a significant difference between Experimental I, Experimental II and Control groups considering their post-test mean scores obtained from SMTML questionnaire dimensions? In order to find answer for this question, Kruskal Wallis $H$ test was used to compare the mean scores between the groups. Table 3 shows Kruskal Wallis $H$ test results regarding the comparison of the groups' post-test scores obtained from SMTML questionnaire dimensions.

Table 3

Kruskal Wallis $H$ test results regarding the comparison of the groups' post-test scores obtained from SMTML questionnaire dimensions.

\begin{tabular}{|c|c|c|c|c|c|c|}
\hline Dimensions & Groups & $\mathrm{N}$ & $\begin{array}{l}\text { Mean } \\
\text { Ranks }\end{array}$ & $H$ & $p$ & $\eta^{2}$ \\
\hline \multirow[t]{3}{*}{ Self-efficacy } & Experimental I & 29 & 49.57 & \multirow{3}{*}{4.748} & \multirow{3}{*}{.093} & \multirow{3}{*}{0.055} \\
\hline & Experimental II & 29 & 46.57 & & & \\
\hline & Control & 29 & 35.86 & & & \\
\hline \multirow[t]{3}{*}{ Active learning strategies } & Experimental I & 29 & 47.33 & \multirow{3}{*}{0.817} & \multirow{3}{*}{.665} & \multirow{3}{*}{0.01} \\
\hline & Experimental II & 29 & 41.55 & & & \\
\hline & Control & 29 & 43.12 & & & \\
\hline \multirow{3}{*}{$\begin{array}{l}\text { Value of mathematics } \\
\text { learning }\end{array}$} & Experimental I & 29 & 51.03 & \multirow{3}{*}{3.627} & \multirow{3}{*}{.163} & \multirow{3}{*}{0.042} \\
\hline & Experimental II & 29 & 41.95 & & & \\
\hline & Control & 29 & 39.02 & & & \\
\hline \multirow[t]{3}{*}{ Performance goal } & Experimental I & 29 & 39.17 & \multirow{3}{*}{3.788} & \multirow{3}{*}{.150} & \multirow{3}{*}{0.044} \\
\hline & Experimental II & 29 & 51.29 & & & \\
\hline & Control & 29 & 41.53 & & & \\
\hline \multirow[t]{3}{*}{ Achievement goal } & Experimental I & 29 & 57.31 & \multirow{3}{*}{12.968} & \multirow{3}{*}{$.002 *$} & \multirow{3}{*}{0.15} \\
\hline & Experimental II & 29 & 38.9 & & & \\
\hline & Control & 29 & 35.79 & & & \\
\hline \multirow{3}{*}{$\begin{array}{l}\text { Learning environment } \\
\text { stimulation }\end{array}$} & Experimental I & 29 & 44.67 & \multirow{3}{*}{0.245} & \multirow{3}{*}{.885} & \multirow{3}{*}{0.003} \\
\hline & Experimental II & 29 & 45.19 & & & \\
\hline & Control & 29 & 42.14 & & & \\
\hline
\end{tabular}

According to the results in Table 3, no statistically significant differences were found between the scores of SMTML questionnaire dimensions for the experimental group I, experimental group II and control groups except for the achievement goal dimension post-test scores. In achievement goal dimension, there was a statistically significant difference between groups $[H(2)=12.968 p<.05]$. In order to find the reason for the difference, Mann Whitney $U$ test was used for the comparisons between the groups. Besides, Bonferonni correction was implemented for critical value. According to Bonferonni correction, the new critical value is found by dividing the current critical value by the number of the made comparisons (Field, 2009). Thus, the critical value was assumed to be 0.0167 because three comparisons were made totally. Table 4 shows Mann Whitney $U$ test results regarding the comparisons of the groups' post test scores obtained from achievement goal dimension. 
Table 4

Mann Whitney $U$ test results regarding the comparison of the groups' post test scores obtained from achievement goal dimension.

\begin{tabular}{|c|c|c|c|c|c|c|c|c|}
\hline Comparison Groups & $N$ & $\begin{array}{l}\text { Mean } \\
\text { Ranks }\end{array}$ & $\begin{array}{l}\text { Sum of } \\
\text { Ranks }\end{array}$ & Mdn & $U$ & $z$ & $P$ & $r$ \\
\hline $\begin{array}{l}\text { Experimental I } \\
\text { Experimental II }\end{array}$ & $\begin{array}{l}29 \\
29 \\
\end{array}$ & $\begin{array}{l}36.10 \\
22.90\end{array}$ & $\begin{array}{l}1047 \\
664 \\
\end{array}$ & $\begin{array}{l}25 \\
22\end{array}$ & 229 & -3.076 & $.002 *$ & 0.49 \\
\hline $\begin{array}{l}\text { Experimental I } \\
\text { Control }\end{array}$ & $\begin{array}{l}29 \\
29 \\
\end{array}$ & $\begin{array}{l}36.21 \\
22.79 \\
\end{array}$ & $\begin{array}{l}1050 \\
661 \\
\end{array}$ & $\begin{array}{l}25 \\
21 \\
\end{array}$ & 226 & -3.161 & $.002 *$ & 0.50 \\
\hline $\begin{array}{l}\text { Experimental II } \\
\text { Control }\end{array}$ & $\begin{array}{l}29 \\
29 \\
\end{array}$ & $\begin{array}{l}31 \\
28 \\
\end{array}$ & $\begin{array}{l}899 \\
812 \\
\end{array}$ & $\begin{array}{l}22 \\
21\end{array}$ & 377 & -0.686 & .493 & 0.11 \\
\hline
\end{tabular}

$* p<.0167$

As it can be seen in Table 4, no statistically significant difference was found between experimental group II and control groups ( $p>$.0167). However, there was a statistically significant difference between experimental group I and experimental group II, and also between experimental group I and control groups $(p<.0167)$.

The second sub problem: Is there a significant difference within Experimental I, Experimental II and Control groups considering their mean scores obtained from SMTML questionnaire dimensions (pretest-posttest)? Wilcoxon signed Rank test was used to compare SMTML questionnaire pretest and posttest scores for each group. Table 5 shows Wilcoxon signed Rank test results regarding the comparison of the pretest-posttest scores of SMTML questionnaire dimensions for the experimental group I.

Table 5

Wilcoxon signed Rank test results regarding the comparison of the pretest-posttest scores of SMTML questionnaire dimensions for the experimental group I

\begin{tabular}{|c|c|c|c|c|c|c|c|}
\hline Dimensions & Post test-Pre test & $N$ & $\begin{array}{l}\text { Mean } \\
\text { Rank }\end{array}$ & $\begin{array}{l}\text { Sum of } \\
\text { Ranks }\end{array}$ & $z$ & $p$ & $r$ \\
\hline \multirow[t]{3}{*}{ Self-efficacy } & Negative Ranks & 9 & 13.22 & 119 & & & \\
\hline & Positive Ranks & 18 & 14.39 & 259 & $-1.686^{* *}$ & 0.092 & .22 \\
\hline & Ties & 2 & & & & & \\
\hline \multirow[t]{3}{*}{ Active learning strategies } & Negative Ranks & 7 & 12.07 & 84.5 & & & \\
\hline & Positive Ranks & 20 & 14.68 & 293.5 & $-2.518^{* * *}$ & $0.012^{*}$ & .33 \\
\hline & Ties & 2 & & & & & \\
\hline \multirow{3}{*}{$\begin{array}{l}\text { Value of mathematics } \\
\text { learning }\end{array}$} & Negative Ranks & 6 & 5.67 & 34 & & & \\
\hline & Positive Ranks & 20 & 15.85 & 317 & $-3.612^{* *}$ & $.000^{*}$ & .47 \\
\hline & Ties & 3 & & & & & \\
\hline \multirow[t]{3}{*}{ Performance goal } & Negative Ranks & 15 & 14.97 & 224.5 & & & \\
\hline & Positive Ranks & 12 & 12.79 & 153 & $-0.856^{* * \cdot k}$ & .392 & .11 \\
\hline & Ties & 2 & & & & & \\
\hline \multirow[t]{3}{*}{ Achievement goal } & Negative Ranks & 4 & 8.25 & 33 & & & \\
\hline & Positive Ranks & 16 & 11.06 & 177 & $-2.703^{* *}$ & $.007^{*}$ & .35 \\
\hline & Ties & 9 & & & & & \\
\hline \multirow[t]{3}{*}{$\begin{array}{l}\text { Learning environment } \\
\text { stimulation }\end{array}$} & Negative Ranks & 9 & 11.33 & 102 & & & \\
\hline & Positive Ranks & 18 & 15.33 & 276 & $-2.099^{* *}$ & $.036^{*}$ & .28 \\
\hline & Ties & 2 & & & & & \\
\hline
\end{tabular}

International Journal of Instruction, January $2018 \bullet$ Vol.11, No.1 
According to the results, no statistically significant differences were found between the pretest and posttest scores of the experimental group I students for self- efficacy and performance goal dimensions $(p>.05)$. On the other hand, there was a statistically significant difference in pretest and posttest scores of active learning strategies, mathematics learning value, achievement goal, and learning environment stimulation $(p<.05)$ dimensions. The differences were found to be in favour of posttest scores. Table 6 shows Wilcoxon signed Rank test results regarding the comparison of the pretestposttest scores obtained from SMTML questionnaire dimensions for the experimental group II

Table 6

Wilcoxon signed Rank test results regarding the comparison of the pretest-posttest scores obtained from SMTML questionnaire dimensions for the experimental group II

\begin{tabular}{|c|c|c|c|c|c|c|c|}
\hline Dimensions & Post test-Pre test & $N$ & $\begin{array}{l}\text { Mean } \\
\text { Rank }\end{array}$ & $\begin{array}{l}\text { Sum of } \\
\text { Ranks }\end{array}$ & $z$ & $p$ & $r$ \\
\hline \multirow{3}{*}{ Self-efficacy } & Negative Ranks & 10 & 13.85 & 138.5 & \multirow{3}{*}{$-1.478^{* * *}$} & \multirow{3}{*}{.139} & \multirow{3}{*}{.19} \\
\hline & Positive Ranks & 18 & 14.86 & 267.5 & & & \\
\hline & Ties & 1 & & & & & \\
\hline \multirow{3}{*}{$\begin{array}{l}\text { Active } \\
\text { learning } \\
\text { strategies }\end{array}$} & Negative Ranks & 7 & 8.43 & 59 & \multirow{3}{*}{$-2.797^{* *}$} & \multirow{3}{*}{$.005^{*}$} & \multirow{3}{*}{.37} \\
\hline & Positive Ranks & 18 & 14.78 & 266 & & & \\
\hline & Ties & 4 & & & & & \\
\hline \multirow{3}{*}{$\begin{array}{l}\text { Value of } \\
\text { mathematics } \\
\text { learning }\end{array}$} & Negative Ranks & 6 & 10.17 & 61 & \multirow{3}{*}{$-2.572^{* *}$} & \multirow{3}{*}{$.01^{*}$} & \multirow{3}{*}{.34} \\
\hline & Positive Ranks & 18 & 13.28 & 239 & & & \\
\hline & Ties & 5 & & & & & \\
\hline \multirow{3}{*}{$\begin{array}{l}\text { Performance } \\
\text { goal }\end{array}$} & Negative Ranks & 13 & 13 & 169 & \multirow{3}{*}{$-0.176^{* * *}$} & \multirow{3}{*}{.860} & \multirow{3}{*}{.02} \\
\hline & Positive Ranks & 12 & 13 & 156 & & & \\
\hline & Ties & 4 & & & & & \\
\hline \multirow{3}{*}{$\begin{array}{l}\text { Achievement } \\
\text { goal }\end{array}$} & Negative Ranks & 11 & 11.27 & 124 & \multirow{3}{*}{$-0.714^{* * * *}$} & \multirow{3}{*}{.475} & \multirow{3}{*}{.09} \\
\hline & Positive Ranks & 9 & 9.56 & 86 & & & \\
\hline & Ties & 9 & & & & & \\
\hline \multirow{3}{*}{$\begin{array}{l}\text { Learning } \\
\text { environment } \\
\text { stimulation }\end{array}$} & Negative Ranks & 9 & 8.17 & 73.5 & \multirow{3}{*}{$-2.606^{* *}$} & \multirow{3}{*}{$.009^{*}$} & \multirow{3}{*}{.34} \\
\hline & Positive Ranks & 17 & 16.32 & 277.5 & & & \\
\hline & Ties & 3 & & & & & \\
\hline$p<.05$ & Based on nega & $\operatorname{ran}$ & & & 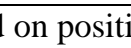 & rank & \\
\hline
\end{tabular}

As seen in Table 6, there was no statistically significant difference between the pretest and posttest scores of the experimental group II students for self- efficacy, performance goal, and achievement goal ( $p>.05)$ dimensions. On the other hand, there was a statistically significant difference in pretest and posttest scores of active learning strategies, mathematics learning value, and learning environment $(p<.05)$ dimensions. The differences were found to be in favour of posttest scores. Table 7 shows Wilcoxon signed Rank test results regarding the comparison of the pretest-posttest scores obtained from SMTML questionnaire dimensions for the control group. 
Table 7

Wilcoxon signed Rank test results regarding the comparison of the pretest-posttest scores obtained from SMTML questionnaire dimensions for the control group.

\begin{tabular}{|c|c|c|c|c|c|c|c|}
\hline Dimensions & Post test-Pre test & $N$ & $\begin{array}{l}\text { Mean } \\
\text { Rank }\end{array}$ & $\begin{array}{l}\text { Sum of } \\
\text { Ranks }\end{array}$ & $z$ & $p$ & $r$ \\
\hline \multirow{3}{*}{ Self-efficacy } & Negative Ranks & 13 & 11.46 & 149 & \multirow{3}{*}{$-0.732^{* * * *}$} & \multirow{3}{*}{.464} & \multirow{3}{*}{.1} \\
\hline & Positive Ranks & 9 & 11.56 & 104 & & & \\
\hline & Ties & 7 & & & & & \\
\hline \multirow{3}{*}{$\begin{array}{l}\text { Active } \\
\text { learning } \\
\text { strategies }\end{array}$} & Negative Ranks & 12 & 15.17 & 182 & \multirow{3}{*}{$-0.169^{* *}$} & \multirow{3}{*}{.866} & \multirow{3}{*}{.02} \\
\hline & Positive Ranks & 15 & 13.07 & 196 & & & \\
\hline & Ties & 2 & & & & & \\
\hline \multirow{3}{*}{$\begin{array}{l}\text { Value of } \\
\text { mathematics } \\
\text { learning }\end{array}$} & Negative Ranks & 14 & 13.86 & 194 & \multirow{3}{*}{$-0.475^{* * * *}$} & \multirow{3}{*}{.635} & \multirow{3}{*}{.06} \\
\hline & Positive Ranks & 12 & 13.08 & 157 & & & \\
\hline & Ties & 3 & & & & & \\
\hline \multirow{3}{*}{$\begin{array}{l}\text { Performance } \\
\text { goal }\end{array}$} & Negative Ranks & 14 & 12.75 & 178.5 & \multirow{3}{*}{$-1.242^{* * *}$} & \multirow{3}{*}{.214} & \multirow{3}{*}{.16} \\
\hline & Positive Ranks & 9 & 10.83 & $\begin{array}{l}170.5 \\
97.5\end{array}$ & & & \\
\hline & Ties & 6 & & & & & \\
\hline \multirow{3}{*}{$\begin{array}{l}\text { Achievement } \\
\text { goal }\end{array}$} & Negative Ranks & 16 & 12.84 & 205.5 & \multirow{3}{*}{$-2.060^{* * *}$} & \multirow{3}{*}{$.039^{*}$} & \multirow{3}{*}{.27} \\
\hline & Positive Ranks & 7 & 10.07 & 70.5 & & & \\
\hline & Ties & 6 & & & & & \\
\hline \multirow{3}{*}{$\begin{array}{l}\text { Learning } \\
\text { environment } \\
\text { stimulation }\end{array}$} & Negative Ranks & 10 & 13.20 & 132 & \multirow{3}{*}{$-1.110^{* *}$} & \multirow{3}{*}{.267} & \multirow{3}{*}{.15} \\
\hline & Positive Ranks & 16 & 13.69 & 219 & & & \\
\hline & Ties & 3 & & & & & \\
\hline
\end{tabular}

As seen in Table 7, there was no significant difference between the pretest and posttest scores of self-efficacy, active learning strategies, mathematics learning value, performance goal, and learning environment stimulation $(p>.05)$ dimensions for the control group. On the other hand, there was a statistically significant difference in pretest and posttest scores of achievement goal $(p<.05)$ dimension. The difference was found to be in favour of pretest scores.

\section{DISCUSSION}

In this research, there was a significant difference only in achievement goal motivation dimension among the methods used in groups. The difference was between experimental group I, in which geometric functions approach was used, and the control group, in which mathematics teaching with traditional method was used, and this difference was in favour of the experimental group I. There was also a significant difference between the experimental group I and the experimental group II, and this difference was in favour of the experimental group I.

These findings indicate that geometric functions approach can be an efficient way in increasing students' motivation for achievement goal. Motivation toward learning reflects the features of inner motivation (Pintrich \& Schunk, 2002) and the students who aim at learning by just a focus on gaining information and skill. They compare new information with previous one. When they face with challenges, they do not give up and go on with their own endeavour or they may want help from others (Brophy, 2010). 
Besides, motivation toward learning has a positive effect on success (Ames, 1992). Learning motivation is important in terms of achievement and the students with high motivation are more successful than the ones with low motivation (Slavin, 2006). The following results indicate how each teaching method performed in the experimental group I, experimental group II and the control groups affected students' motivation during the experimental process

According to the results obtained from the study, it was found that geometric functions approach and dynamic mathematics software which supported the mathematics teaching and dynamic mathematics software which supported the mathematics teaching and mathematics teaching with traditional method did not lead a significant difference in students' motivation toward self-efficacy. Self-efficacy is a kind of motivation (Sternberg, 2005) and it is important in explaining the school performance of students (Slavin, 2006). Self-efficacy is the beliefs of people about their competences (Bandura, 1994). However, self-efficacy does not show the actual capacity of the person. Selfefficacy is how one understands its own capacity. As a result, not all three methods used in this study were effective in increasing students' self-efficacy.

On the other hand, it was found that geometric functions approach and dynamic mathematics software which supported the mathematics teaching and dynamic mathematics software which supported the mathematics teaching using the traditional method didn't lead a significant difference in students' motivation toward performance goal. Students who have performance goal do not aim at gaining information and skill. They just aim at testing their own abilities. They learn information superficially but not deeply and generally they just memorize. When they face with challenges they give up or cheat from their friends (Brophy, 2010). In the study, it was seen that motivation toward performance goal did not change in all groups during the process, which is a desired situation in education since motivation toward performance reflects the features of external motivation (Pintrich \& Schunk, 2002). On the contrary, in many researches, negative correlation was found between external motivation and success (Lepper, Corpus \& lyengar, 2005; Lemos \& Veríssimo, 2014; Pintrich, Smith, García \& McKeachie, 1993).

There was a significant difference in favour of posttest, in achievement goal motivation of the experimental group, in which geometric functions approach and dynamic mathematics software were used. In experimental group II, dynamic mathematics software which supported the mathematics teaching did not make a significant difference in motivation toward achievement goal. While it is important to develop ability in learning goal, in performance goal it is important to show ability (Brophy, 2010). The students who learn to develop their abilities use more effective learning strategies than the ones who want to show their success (Boekaerts, 2002). The students who have high motivation toward achievement do not give up when they encounter challenges and they endeavour until they achieve (Slavin, 2006). In this study, the method applied to the experimental group I increased student motivation toward learning significantly. This is a desired situation in terms of education. As a conclusion, education should increase students' inner motivation as much as possible (Slavin, 2006). 
Geometric functions approach, dynamic mathematics software which supported the mathematics teaching and dynamic mathematics software which supported the mathematics teaching made a significant difference in active learning strategies and value of mathematics learning, which was in favour of posttest. In control group there was no significant difference.

Geometric functions approach, dynamic mathematics software which supported the mathematics teaching and dynamic mathematics software which supported the mathematics teaching made a significant difference in learning environment stimulation, which was in favour of posttest. There was no significant difference in control group. Çavaş (2011) reported in his study that student's higher grades affect the value of learning, active learning strategies, achievement goal and learning environment situation negatively. In the experimental group I and experimental group II, there were significant increases in value of learning, active learning strategies, learning environment situation. In the experimental group II, motivation toward learning did not change but in Experimental group I it increased significantly. There are some reports, which state if the level of the grades increases motivation toward learning decreases (Çavaş, 2011; Ekici, Kaya \& Mutlu, 2014). In this study, self-efficacy and motivation toward performance goal, which are among the factors of motivation toward learning, did not change in all groups. However, while mathematics learning value, active learning strategies and learning environment stimulation increased significantly in the experimental group I and the experimental group II, there was no change in control group. Motivation toward achievement increased only in the experimental group I. Teachers should motivate the students toward learning rather than the scores they will get. For that reason, the materials they use should be practicable and attractive (Slavin, 2006). The individuals who have motivation toward learning tend to compare their previous learning with the old ones (Anderman \& Young, 1994). The reason why the motivation toward achievement goal was high in experimental group I may be because of the fact that the method applied in this group attracted the student's attention. Besides, the applied method might enhance students' motivation to make up a relation between transformation geometry they learned in the past and functions subject. In this study, a significant increase was seen in motivation levels of the experimental groups. Especially, the motivation toward achievement goal was high in experimental group I in which geometric functions approach and dynamic mathematics software were used. Many researchers have found a significant and positive relation between motivation and success (Amrai, Motlagh, Zalani \& Parhon, 2011; Chow \& Yong, 2013). Therefore, it is important to choose the methods which motivate students and to use them in teaching process as it was performed in this study.

\section{CONCLUSION}

The purpose of this research was to investigate the effects of using geometric functions approach on 9th grade students' motivation levels toward mathematics in functions unit. Participants of this study were 87 students who were ongoing in the first year of high school in Turkey. In this research, pretest and posttest control group quasi-experimental 
design was used. The data of this study were collected through Students' Motivation toward Mathematics Learning questionnaire".

The results of this study indicate that using geometric functions approach in the learning process of function concept has a significant effect on students' achievement goal motivation. It indicates that geometric functions approach can be an efficient way in increasing students' motivation for achievement goal. It may be said that the geometric functions approach has attracted students' attention.

Geometric functions approach, dynamic mathematics software which supported the mathematics teaching and only dynamic mathematics software which supported the mathematics teaching made a significant difference in active learning strategies, value of mathematics learning and learning environment stimulation, which was in favour of posttest scores. However, there was no a significant difference in the control group.

There was a significant difference, in favour of posttest, in achievement goal motivation of the experimental group I, in which geometric functions approach and dynamic mathematics software was used. In the experimental group II, dynamic mathematics software which supported the mathematics teaching did not make a significant difference in motivation toward achievement goal. In the control group, it was observed that there was a decrease in achievement motivation.

In this study, only the effects of geometric functions approach on motivation were examined. The effects of geometric functions approach on other affective domains can also be examined in further studies. The study can be repeated at different schools and cultures to improve generalizability. Also, the following suggestions can be made in the light of the findings of the study. Due to the fact that the geometric functions approach increases achievement goal motivation, mathematics teachers can teach functions using the geometric functions approach since the students motivated for achievement goal tend to become more successful. Besides, the Ministry of Education may organize in-service trainings for mathematics teachers to disseminate geometric functions approach.

\section{REFERENCES}

Ames, C. (1992). Classrooms: Goals, structures, and student motivation. Journal of Educational Psychology, 84, 261-271.

Amrai, K., Motlagh, S. E., Zalani, H. A., \& Parhon, H. (2011). The relationship between academic motivation and academic achievement students. Procedia-Social and Behavioral Sciences, 15, 399-402.

Anderman, E. M., \& Young, A. J. (1994). Motivation and strategy use in science: Individual differences and classroom effects. Journal of Research in Science Teaching, 31(8), 811-831.

Bacanl, H., \& Sahinkaya, O. (2011). The adaptation study of academic motivation scale into Turkish. Procedia-Social and Behavioral Sciences, 12, 562-567. 
Bakar, K. A., Ayub, A. F. M., Luan, W. S., \& Tarmizi, R. A. (2010). Exploring secondary school students' motivation using technologies in teaching and learning mathematics. Procedia-Social and Behavioral Sciences, 2(2), 4650-4654.

Bandura, A. (1994). Self-efficacy. In V. S. Ramachaudran (Ed.), Encyclopedia of human behavior (pp. 71-81). New York: Academic Press. (Reprinted in H. Friedman [Ed.], Encyclopedia of mental health. San Diego: Academic Press, 1998).

Boekaerts, M. (2002). Motivation to learn. H. J. Walberg (Ed.), In Educational Practices. Brussels: International Academy of Education.

Brophy, J. E. (2010). Motivating students to learn (3rd Ed.). Madison, NY: Routledge.

Chow, S. J., \& Yong, B. C. S. (2013). Secondary school students' motivation and achievement in combined science. US-China Education Review B, 3(4), 213-228.

Common Core State Standards Initiative. (2010). Common core state standards for mathematics. Washington, DC: National Governors Association Center for Best Practices and the Council of Chief State School Officers. Retrieved from http://www.corestandards.org/Math

Ekici, D.İ., Kaya, K., \& Mutlu, O. (2014). Investigating of Motivation about Science Learning of Middle School Students to Different Variables: The Case of Usak Province. Mersin University Journal of the Faculty of Education, 10(1), 13-26.

Field, A. (2009). Discovering statistics using SPSS, (3rd Ed.). Thousand Oaks, CA: Sage.

Hambleton, R. K. (2005). Issues, designs, and technical guidelines for adapting tests into multiple languages and cultures. In R. K. Hambleton, P. F. Merenda, \& C. D. Spielberger (Eds.). Adapting educational and psychological tests for cross-cultural assessment. NJ: Lawrence Erlbaum.

Lee, O., \& Brophy, J. (1996). Motivational patterns observed in sixth-grade science classrooms. Journal of Research in Science Teaching, 33(3), 303-318.

Lemos, M. S., \& Veríssimo, L. (2014). The relationships between intrinsic motivation, extrinsic motivation, and achievement, along elementary school. Procedia-Social and Behavioral Sciences, 112, 930-938.

Lepper, M. R., Corpus, J. H., \& Iyengar, S. S. (2005). Intrinsic and extrinsic motivational orientations in the classroom: age differences and academic correlates. Journal of Educational Psychology, 97(2), 184.

Pintrich, P. R., \& Schunk, D. H. (2002). Motivation in education: Theory, research, and applications (2nd Ed.). Upper Saddle River, N.J.: Merrill.

Pintrich, P. R., Smith, D. A., García, T., \& McKeachie, W. J. (1993). Reliability and predictive validity of the motivated strategies for learning questionnaire (MSLQ). Educational and Psychological Measurement, 53(3), 801-813. 
Slavin, R. E. (2006). Educational psychology: Theory and practice (8th Ed.). Boston, MA: Pearson/Allyn \& Bacon.

Steketee, S. (2012, July). Why students should begin the study of function using Geometric points, not numbers! 12th International Congress on Mathematical Education (ICME12). COEX, Seoul, Korea.

Steketee, S., \& Scher, D. (2016). Connecting Functions in Geometry and Algebra. Mathematics Teacher, 109(6), 448-455.

Sternberg, R. J. (2005). Intelligence, competence, and expertise. In Dweck, C. S., \& Elliot, A. J. (Eds.), Handbook of competence and motivation (pp. 15-30). New York, NY: Guilford

Tuan, H. L., Chin, C. C., \& Shieh, S. H. (2000, April). Students' motivation toward learning physical science- A case from four classes of Taiwanese students. National Association for Research in Science Teaching, New Orleans, Louisiana.

Tuan, H. L. Chin, C. C., \& Shieh, S. H. (2005). The development of a questionnaire to measure students' motivation towards science learning. International Journal of Science Education, 27(6), 639-654.

Urdan, T. C., \& Maehr, M. L. (1995). Beyond a two-goal theory of motivation and achievement: A case for social goals. Review of Educational Research, 65(3), 213-243.

Wlodkowski, R. J. (2008). Enhancing adult motivation to learn: A comprehensive guide for teaching all adults. (3rd Ed.). San Francisco: Jossey-Bass, A Wiley Imprint. 